\title{
THE PROPOSAL OF A TOOL FOR CANDIDATE'S SELECTION FOR EMPLOYMENT: THE CASE OF SURVEY INTERVIEWERS
}

\author{
Alina Morosanu, Elisabeta Jaba, Daniela Serban*
}

\begin{abstract}
This study purpose is a questionnaire development used to quantify survey interviewer characteristics. Five dimensions of personality were used: conscientiousness, extraversion, agreeableness, emotional stability and openness. Those dimensions where measured using a Likert scale with 6 points. In total, 107 survey interviewers from a branch of private companies specialized in public opinion research answered the questionnaire's questions. Reliability of the questionnaire was assessed by internal consistency. A preliminary list of 25 items was prepared as a starting point. After evaluation of validity, five items were rejected. The new measurement instrument with 20 items was finally developed. The content validity index for the final questionnaire was found acceptable. Results showed that final questionnaire was internally consistent.
\end{abstract}

Keywords: survey interviewer, characteristics of personality, questionnaire, reliability, validity JEL Classification: C83, J21, J24

\section{Introduction}

A survey is often the best method to collect data from which may be obtained information and feedback on a specific topic asking questions of individuals and then generalizing the results to the group represented by the respondents. The questionnaire can be also the base of a periodical evaluation of the employees of a survey company. In literature (Tourangeau et al., 2000; Kenneth et al., 2002, McDonald and Adam, 2003; de Leeuw, 2005; Couper, 2005) there are presented different modes of data collection: ACASI (computer assisted self administered interviews), ASAQ (audio self administered questionnaire), CAPI (computer assisted personal interviewing), CASI (computer assisted self interviewing), CATI (computer assisted telephone interviewing), DBM (disk by mail), PAPI (paper and pencil personal interviewing), PDE (prepared data entry/web surveys), SAQ (self administered questionnaires), TDE (touchtone data entry) or VRE (voice recognition entry). These modes of data collection differ in respect to the method of contacting the respondents and questionnaire administration. In one group of methods, the questionnaires are delivered by an interviewer, in another one the questionnaires are administered without approach.

* Alina Morosanu, Department of Accounting, Computer Science and Statistics, Alexandru Ioan Cuza University Iasi, Romania (alynamorosanu@yahoo.com);

Elisabeta Jaba, Department of Accounting, Computer Science and Statistics, Alexandru Ioan Cuza University Iasi, Romania (ejaba@uaic.ro);

Daniela Serban, Department of Statistics and Econometrics, Academy of Economic Studies

Bucharest, Romania (danielaserban2002@yahoo.com). 
When a questionnaire is administered by an interviewer, there might be differences in asking questions and recording answers. Many researchers (Hansen, 2007; Dillmana et al., 2009; Davis et al., 2010; Haunberger, 2010; Dykema et al., 2012) have shown that those differences may be caused, among other factors, by socio-demographic, physical or personality characteristics of an interviewer. Thus, Schuman and Converse (1971), Singer et al. (1983), Webster (1996), Ford, Norris (1997), Davis, Silver (2003), Olson, Bilgen (2011), Liu and Stainback (2013), Blaydes and Gillum (2013) have shown that sociodemographic characteristics of an interviewer like gender, race, age, ethnicity, religion, educational level or experience may have a significant influence on the interpretation of questionnaire questions and on the formulation of respondents answers. According to Joseph (1982), Burger et al. (2001) and Murphy et al. (2010), physical characteristics of a survey interviewer like weight, height, facial expression or voice may determine the attractiveness and this affects the respondent perceived trustworthiness. This is possible because, in general, people are more inclined to comply with the requests of someone whom they like or see as similar to themselves. Personality characteristics of a survey interviewer are very important too. Hox and de Leeuw (2002), Abbott et al. (2003), Blohm et al. (2007), Durrant et al. (2010), Jäckle et al. (2013) have shown that characteristics like extroversion, adaptability, assertiveness, confidence or agreeability may affect the performance of a survey interviewer.

However, little is known about how to explain why some interviewers are more successful than others at persuading respondents to participate and about which skills or attitudes could be relevant at the recruitment and training of survey interviewers. Taking in consideration those aspects, the purpose of this paper is to create and validate a questionnaire that can be used for survey interviewer's selection. In order to do this, the first objective of this research work is to identify in literature those characteristics that define the dimensions of survey interviewer personality. The second objective is to validate the created questionnaire if it is verified on survey interviewers which are employees in a branch of a public opinion research institute. If the results obtained after data processing validate the dimensions of survey interviewer's personality then the questionnaire may be used in their selection process.

\section{Research Methodology}

Our research aims to achieve a questionnaire that can be used as a tool in survey interviewer's selection. For survey interviewer's selection we must know the dimensions of personality and the characteristics specific to a survey interviewer. In literature, to characterize the personality types there are used three approaches: the study of personality traits represented by the Big Five personality dimension (Digman, 1990); study of traits represented by the Big Six interest types (Holland, 1985); correlated study of the 2 approaches (Mount et al., 2005). In our study, the choice of the dimensions of survey interviewer personality is based on the Big Five - factor structure of personality which describes the basic dimensions of normal personality (Goldberg, 1992). For each dimension there were associated characteristics specific to a survey interviewer (Table 2). 


\subsection{Population}

The population observed is represented by employed survey interviewers in order to identify the needed characteristics for an efficient interviewer. To request the participation in our study notices were sent to each survey interviewer. We received affirmative responses from all 107 subjects working as survey interviewers. Table 1 presents information on these participants. This information was provided by the Human Resources Department of the Public Opinion Research Institute.

Table 1 | Socio-Demographical Characteristics of Respondents

\begin{tabular}{|l|r|r|}
\hline Characteristics & (N) & $\begin{array}{c}\text { Percentage } \\
\text { (\%) }\end{array}$ \\
\hline Gender & 12 & 11.2 \\
Male & 95 & 88.8 \\
Female & & \\
\hline Age & 7 & 6.5 \\
less than 20 years & 67 & 62.6 \\
20-24 years & 30 & 28.0 \\
25-30 years & 3 & 2.8 \\
over 30 years & & \\
\hline Education level & 27 & 25.2 \\
High school & 48 & 44.9 \\
University (ongoing) & 21 & 19.6 \\
University (licensed) & 2 & 1.2 \\
Postgraduate (ongoing) & 9 & 8.4 \\
Postgraduate (licensed) & & \\
\hline Seniority & & 14.0 \\
less than 6 months & 15 & 46.7 \\
6 months-1 year & 50 & 26.2 \\
1-1.5 years & 28 & 13.1 \\
over 1.5 years & 14 & \\
\hline
\end{tabular}

Source: Results obtained after data processing.

The information presented in Table 1 showed that $88.8 \%$ of respondents are female. The fact that in a company specialized in public opinion research survey female interviewers are more frequent than male interviewers is confirmed by the literature (Stoetzel and Girard, 1973).

Also, we observed that many of our respondents are young. More than half of them (62.6\%) have between 20-24 years. This situation is also sustained in literature. Herzog and Willard (1988) showed that in different types of surveys, response rates are found to decline linearly with increasing age. 


\subsection{Questionnaire}

Questionnaire administration was carried out in three steps. First, to our survey interviewers there were given survey instructions. For this purpose they received a questionnaire, pencil and paper and were assured that their answers would be treated anonymously and confidentially. Also, they were directed to a private office to complete their task. The second step was carried out by survey interviewers themselves. They were left alone to complete their questionnaires at their own speed. They were requested to inform us when they finished and to give us their written results. In a third step, the respondents were requested to review each of the questions and to indicate if they had found a particular question that is disturbing in any way. We proceeded in this way to determine how serious each respondent had been in expressing his opinion.

To achieve the questionnaire that was used to quantify survey interviewer's characteristics, we selected an appropriate set of questions to ask. This aspect is very important because, it is possible that the content of a questionnaire will be regarded by respondents as highly personal and this may lead to the manifestation of feelings of anxiety and reluctance to answer questions openly and honestly (Fillmore, 1999). To avoid this problem, we constructed suitable questions/items.

After items construction, for items selection we used different types of statistical analysis. Thus, descriptive analysis was used to study items distribution, principal components analysis (PCA) to identify the relationships between items, the content validity ratio (CVR) to test the content validity for each item, the content validity index (CVI) to analyse the overall content validity of the entire questionnaire and Cronbach Alpha Coefficient to evaluate the reliability.

Taking the example of the Big Five personality test, personality characteristics of a survey interviewer can be clustered in five dimensions: conscientiousness, extraversion, agreeableness, emotional stability and openness. These dimensions were associated with a set of characteristics presented in Table 2 .

Table 2 | Dimensions and Characteristics of a Survey Interviewer

\begin{tabular}{|l|l|}
\hline Dimension & \multicolumn{1}{c|}{ Characteristics } \\
\hline Conscientiousness & - disciplined, efficient, planned, rigorous, responsible \\
Extraversion & - active, assertiveness, dynamic, open, sociable \\
Agreeableness & - compassionate, cooperative, friendly, generous, helpful \\
Emotional stability & - control, calm, self-confidence, stress, tolerant \\
Openness & - adventure, creativity, curiosity, experience, independence \\
\hline
\end{tabular}

Source: Processed after Gosling et al. (2003)

The dimensions recorded through responses given by respondents at questions were included in a questionnaire. Each characteristics from Table 2 was expressed through 
an item or a statement. Considering the characteristics established in order to define the dimensions of survey interviewer personality, the items were extracted from the International Personality Item Pool (http://ipip.ori.org/) (Goldberg et al., 2006) (Table 3).

Table 3 | List with Defined Items/Statements

\begin{tabular}{|c|c|c|c|}
\hline \multirow{2}{*}{$\begin{array}{l}\text { Personality } \\
\text { dimension }\end{array}$} & \multirow{2}{*}{$\begin{array}{l}\text { Characteristics } \\
\text { disciplined } \\
\text { efficient } \\
\text { rigorous } \\
\text { planned } \\
\text { responsible }\end{array}$} & \multicolumn{2}{|r|}{ Item/Statement } \\
\hline & & $\begin{array}{l}\text { Item } 1 \\
\text { Item } 2 \\
\text { Item } 3 \\
\text { Item } 4 \\
\text { Item } 5\end{array}$ & $\begin{array}{l}\text { I prefer to put things back in their proper place. } \\
\text { I pay attention to details. } \\
\text { I like to do things rigorously. } \\
\text { In my work I always follow a schedule. } \\
\text { I do my duties with responsibility. }\end{array}$ \\
\hline Extraversion & $\begin{array}{l}\text { active } \\
\text { assertiveness } \\
\text { dynamic } \\
\text { open } \\
\text { sociable }\end{array}$ & $\begin{array}{l}\text { Item } 6 \\
\text { Item } 7 \\
\text { Item } 8 \\
\text { Item } 9 \\
\text { Item } 10\end{array}$ & $\begin{array}{l}\text { I like to be active. } \\
\text { I have an assertive personality. } \\
\text { I'm full of energy. } \\
\text { I'm open around people. } \\
\text { I am sociable around strangers. }\end{array}$ \\
\hline Agreeableness & $\begin{array}{l}\text { cooperative } \\
\text { friendly } \\
\text { generous } \\
\text { compassionate } \\
\text { helpful }\end{array}$ & $\begin{array}{l}\text { Item } 11 \\
\text { Item } 12 \\
\text { Item } 13 \\
\text { Item } 14 \\
\text { Item } 15\end{array}$ & $\begin{array}{l}\text { I like to cooperate with others. } \\
\text { I sympathize with others' feelings. } \\
\text { I take time out for others. } \\
\text { I feel others' emotions. } \\
\text { I'm helpful and unselfish with others. }\end{array}$ \\
\hline Emotional stability & $\begin{array}{l}\text { control } \\
\text { calm } \\
\text { self-confidence } \\
\text { stress } \\
\text { tolerant }\end{array}$ & $\begin{array}{l}\text { Item } 16 \\
\text { Item } 17 \\
\text { Item } 18 \\
\text { Item } 19 \\
\text { Item } 20\end{array}$ & $\begin{array}{l}\text { I'm not easily upset. } \\
\text { I remain calm in tense situations. } \\
\text { I am determined and with spirit of initiative. } \\
\text { I handle stress well. } \\
\text { I'm tolerant with others. }\end{array}$ \\
\hline Openness & $\begin{array}{l}\text { adventure } \\
\text { creativity } \\
\text { curiosity } \\
\text { experience } \\
\text { independent }\end{array}$ & $\begin{array}{l}\text { Item } 21 \\
\text { Item } 22 \\
\text { Item } 23 \\
\text { Item } 24 \\
\text { Item } 25\end{array}$ & $\begin{array}{l}\text { I like to do something really adventurous. } \\
\text { I'm original and often I have excellent ideas. } \\
\text { I'm curious about many different things. } \\
\text { I have many experiences at work. } \\
\text { I like to be independent. }\end{array}$ \\
\hline
\end{tabular}

Source: International Personality Item Pool (http://ipip.ori.org/)

Considering the types of items/statements and the possible responses, a first problem to solve was that of defining the scales for the measurement of each characteristics. In literature (Michell, 1986; Jaba, 2002) the principal types of scale used to quantify a phenomenon are: nominal scale, ordinal scale, interval scale, ratio scale, intensity scale and opinion scale. For our items/statements a scale that reflects the frequency with which a certain characteristics of personality occurs must be chosen (Brown, 2010). Regarding this aspect, Preston and Colman (2000) and Lee and Peak (2014) argued that, the most valid and discriminating scale is that with six or more points. Therefore, for items presented in Table 3 we used the ordinal scale coded from 1 to 6 (1- NEVER, 2- RARELY, 3-SOMETIMES, 4-OFTEN, 5-VERY OFTEN, 6-ALWAYS). Thus, the new questionnaire has 25 features and questions regarding socio-demographical characteristics like: gender 
(1- Male, 2- Female), age (1-less than 20 years, 2- 20-24 years, 3- 25-30 years, 4- more than 30 years), educational level (1- High school, 2- University (ongoing), 3- University (licensed), 4- Postgraduate (ongoing), 5- Postgraduate (licensed)) and seniority (1- less than 6 months, 2- 6 months-1 year, 3-1-1.5 years, 4- 1.5-2 years, 5- more than 2 years).

An important aspect for the fulfillment of our research objectives was to test the normal distribution of responses for each statement. This approach helped us to identify the consistencies in the respondents' answers. The next step was to describe the relations between items. To achieve this, we could use a multivariate statistical analysis method like principal component analysis (PCA) (Michell, 1997; Härdle and Simar, 2003; Johnson and Wichern, 2007). The relationships between considered items $(\mathrm{Xj})$ and components $(\mathrm{Ck})$ can be written as a classical regression equation as follows:

$$
C_{k}=b_{1} X_{1}+b_{2} X_{2}+\ldots+b_{j} X_{j}+\ldots+b_{p} X_{p}
$$

Coefficients bj are coefficients associated to initial items $\mathrm{Xj}$ and show the connection between different items and the latent variables $\mathrm{Ck}$. We note that the variables used in PCA reflect only the correlations between items. According to Kline (1993) to a common factor of a group of items there does not correspond necessarily to a characteristics of respondents. Using descriptive analysis and principal component analysis (PCA) there can be analysed items collinearity. However, the removal of some items should not be made before checking the validity and reliability (Cortina, 1993).

In literature (Haynes et al, 1995; Goodwin, 2009; Waltz et al., 2010) can be identified several types of validity: predictive validity, concurrent validity, content validity and construct validity. In this study, we test the content validity using a quantitative measure called content validity ratio (CVR) (Lawshe, 1975). CVR offers information about item level validity and can be calculate as

$$
C V R=\frac{n_{e}-N / 2}{N / 2}
$$

where $n_{e}$ is the number of respondents which considered the item to be "ALWAYS" and $\mathrm{N}$ is the total number of respondents. Lawshe (1975) argues that the utility of the CVR can be derived from the following characteristics:

- When fewer than half say "ALWAYS", the CVR is negative;

- When half say "ALWAYS" and half do not, the CVR is 0;

- When all say "ALWAYS", the CVR is computed to be 1.00;

- When the number saying "ALWAYS" is more than half, but less than all, the CVR is between 0 and 0.99 .

In other words, CVR can take values between -1 and 1 . The closer to 1 the CVR is, the more essential the item is considered to be. Conversely, the closer to -1 the CVR is, the more non-essential it is. To compute the mean for each item, the following conversion was done for the values reflected in the questionnaire: ALWAYS or VERY OFTEN was replaced by 2; OFTEN or SOMETIMES - was replaced by 1 ; RARELY or NEVER - was replaced by 0 . Only those components and links with CVR values and meeting the minimum values were retained in the final model. 
To select items of final questionnaire, the following criteria were applied:

- $\quad$ accept if CVR is equal to or larger than 0.75 ;

- $\quad$ accept if CVR is between 0 and 0.75 and the mean of items/statements is higher than 1.5 .

A mean value higher than 1.5 may indicate that, the mean of items is closer to the value "ALWAYS or OFTEN" than to the value "RARELY or NEVER". A CVR value of 0 indicates that the respondents are undecided and that not less than fifty per cent of the respondents believed that the item is "ALWAYS or OFTEN";

- $\quad$ reject if CVR is less than 0 and the mean is smaller than 1.5. This means that it will be impossible to include any item that was not judged to be essential by at least half of the respondents, or any item possessing a mean of judgments that is closer to "RARELY or NEVER" than to "ALWAYS or OFTEN" (Allahyarri et al., 2011).

After items/statements have been identified for inclusion in the final form, according for the whole questionnaire was computed the content validity index (CVI). According Lawshe (1975), CVI is the mean of the CVR values of the retained items and can be calculated as:

$$
C V I=\frac{\sum_{n}^{1} C V R}{\text { total number of accepted items }}
$$

The overall content validity will be higher if the value of the CVI is closer to 0.99 and vice versa.

Reliability/internal consistency of a questionnaire can be evaluated using Cronbach Alpha coefficient. In literature (Cronbach, 1951; Crano and Brewer, 1973; Mendoza et al, 2000; Osburn, 2000) Cronbach Alpha coefficient is defined as follows:

$$
\alpha=\frac{p}{p-1}\left[1-\frac{\sum_{i=1}^{p} \sigma_{i}^{2}}{\sigma_{T}^{2}}\right]
$$

where $p$ is the number of items ( $p$ must be 2 or higher), $\sigma_{i}^{2}$ is the variance of the ith item, $i=1,2, \ldots, p$ and $\sigma_{T}^{2}$ is the sum of the item variances and co-variances: $\sigma_{T}^{2}=\sum_{i=1}^{p} \sigma_{i}^{2}+\sum_{i \neq} \sum_{j} \sigma_{i j}$

In general, Cronbach alpha coefficient can take values between 0.5 and 0.9 . Thus, if $\alpha \geq 0.9$ the internal consistency is excellent, if $0.8 \leq \alpha<0.9$ the internal consistency is good, if $0.7 \leq \alpha<0.8$ the internal consistency is acceptable, if $0.6 \leq \alpha<0.7$ the internal consistency is questionable, if $0.5 \leq \alpha<0.6$ the internal consistency is poor and if $\alpha<0.5$ the internal consistency is unacceptable.

Data analysis was made in R statistical software. 


\section{Results}

\subsection{Descriptive statistics analysis}

With the data obtained after questionnaire administration we created a database using statistical software R. After the organization, processing and verification of the database we tested the normal distribution of responses for each item/statement. Because the considered items are measured using ordinal scale there were obtained the frequencies of each type of response (Table 4).

Table 4 | Descriptive Statistics Analysis

\begin{tabular}{|c|c|c|c|c|c|c|c|}
\hline \multirow{2}{*}{$\begin{array}{l}\text { Item/ } \\
\text { Statement }\end{array}$} & \multicolumn{7}{|c|}{ Frequency } \\
\hline & $\begin{array}{l}\text { NEVER } \\
\text { (1) }\end{array}$ & $\begin{array}{l}\text { RARELY } \\
\text { (2) }\end{array}$ & $\begin{array}{l}\text { SOMETIMES } \\
\text { (3) }\end{array}$ & $\begin{array}{l}\text { OFTEN } \\
\text { (4) }\end{array}$ & $\begin{array}{c}\text { VERYOFTEN } \\
\text { (5) }\end{array}$ & $\begin{array}{c}\text { ALWAYS } \\
\text { (6) }\end{array}$ & Total \\
\hline Item 1 & - & 3 & 2 & 2 & 7 & 93 & 107 \\
\hline Item 2 & - & 3 & 4 & 3 & 7 & 90 & 107 \\
\hline Item 3 & 1 & 1 & 2 & 3 & 13 & 87 & 107 \\
\hline Item 4 & 13 & 16 & - & - & 1 & 77 & 107 \\
\hline Item 5 & 1 & 2 & 4 & 3 & 5 & 92 & 107 \\
\hline Item 6 & 13 & 14 & - & - & - & 80 & 107 \\
\hline Item 7 & 9 & 18 & 2 & 3 & 2 & 73 & 107 \\
\hline Item 8 & - & - & 2 & 2 & 7 & 96 & 107 \\
\hline Item 9 & - & 1 & 1 & 5 & 8 & 92 & 107 \\
\hline Item 10 & 17 & 15 & 1 & 2 & 3 & 69 & 107 \\
\hline Item 11 & 1 & 3 & 7 & 5 & 5 & 86 & 107 \\
\hline Item 12 & 1 & - & 1 & 1 & 5 & 99 & 107 \\
\hline Item 13 & - & - & 2 & 6 & 10 & 89 & 107 \\
\hline Item 14 & - & 1 & 1 & 5 & 7 & 93 & 107 \\
\hline Item 15 & - & - & 1 & 1 & 7 & 98 & 107 \\
\hline Item 16 & 14 & 19 & 5 & 1 & 1 & 67 & 107 \\
\hline Item 17 & - & 2 & 3 & 2 & 10 & 90 & 107 \\
\hline Item 18 & - & - & 1 & 5 & 19 & 82 & 107 \\
\hline Item 19 & - & 1 & 3 & 4 & 10 & 89 & 107 \\
\hline Item 20 & - & - & 3 & 3 & 20 & 81 & 107 \\
\hline Item 21 & - & 1 & 1 & 1 & 8 & 96 & 107 \\
\hline Item 22 & - & - & 1 & 3 & 20 & 83 & 107 \\
\hline Item 23 & - & 1 & 6 & 5 & 15 & 81 & 107 \\
\hline Item 24 & - & - & 2 & 2 & 10 & 93 & 107 \\
\hline Item 25 & - & 2 & 2 & 5 & 20 & 78 & 107 \\
\hline
\end{tabular}

Source: Our own calculations. 
From the results obtained in Table 4, we observe that more than $70 \%$ of respondents assign for frequency categories "VERY OFTEN" and "ALWAYS", which highlights specific characteristics for a specific dimension.

\subsection{Identifying the association between characteristics and personality dimensions}

In order to study the relationships between characteristics and personality dimensions we applied principal component analysis (PCA). After data processing, we obtained a p-value $<0.05$ associated to $\chi^{2}$ (value of 5,064.43) and a value of 0.871 for KaiserMeyer-Olkin Measure (KMO). Those results show that between characteristics and personality dimensions there are significant statistical connections and our solution is very good. Also, largest eigenvalue (12.185) corresponds to the first dimension which explains $48.742 \%$ of total variance of defining characteristics of the personality dimensions. The first 3 dimensions explain $74.738 \%$ of total inertia (Table 5). This result shows that, the first 3 dimensions are most important in explaining the personality of a survey interviewer.

Table 5 | Extracted Variances

\begin{tabular}{|l|c|c|c|c|c|}
\hline Eigenvalues & $\operatorname{Dim} \mathbf{1}$ & $\operatorname{Dim} \mathbf{2}$ & $\operatorname{Dim} \mathbf{3}$ & $\operatorname{Dim} \mathbf{4}$ & $\operatorname{Dim} \mathbf{5}$ \\
\hline Variance & 12.185 & 4.303 & 2.196 & 1.178 & 1.046 \\
\hline \% of variance & 48.742 & 17.214 & 8.783 & 4.710 & 4.184 \\
\hline Cumulative \% of variance & 48.742 & 65.955 & 74.738 & 79.448 & 83.632 \\
\hline
\end{tabular}

Source: Our own calculations.

In Table A1 from Appendix A there are presented details regarding the value of each item/statement for the first 3 dimensions (Dim 1, Dim 2, Dim 3) and contribution to their construction ( $\cos 2)$. Analysing the results from Table A1, Appendix A, we observe that the first dimension (Dim 1) is associated with the following items: Item 1, Item 2, Item 3, Item 5, Item 8, Item 12, Item 17, Item 18, Item 19, Item 21, Item 22, Item 23, Item 24 and Item 25. The second factorial axis (Dim 2) is represented by items like: Item 6, Item 7, Item 10, Item 14 and Item 16. The third dimension (Dim 3) is represented by items: Item 4, Item 9, Item 11, Item 13 and Item 20. This result is confirmed by correlations between items and dimensions (Figure 1).

From Figure 1 we observe that there are three groups of items between which different statistical connections exist. Thus, one group is represented by a set of 5 items (Item 4, Item9, Item11, Item13 and Item20), a second group is represented by a set of 14 items (Item 1, Item 2, Item 3, Item 5, Item 8, Item 12, Item 17, Item 18, Item19, Item 21 , Item 22, Item 23, Item 24 and Item 25), a third group is represented by a set of 6 items (Item 6, Item7, Item 10, Item 14, Item 16). Also, we can observe that are positive and negative correlations between those groups. An explanation of this result is that, there 
is a concordance of the way in which the respondents answered at our statements. In this case, we must read carefully each statement to see which is the common aspect defining the group. Also, it can happen that in a dimension which brings together items of similar meaning to appear and items that relates to a different reality, but between which is a very close correlation. This is the case of items 4, 6, 7, 10 and 16 (see also weak correlations obtained from PCA between items in Table A2 from Appendix A). On the other hand, it must be considered the fact that the grouping of items by PCA should not be taken to be absolute, but indicative.

\section{Figure 1 | Variables Factor Map PCA}

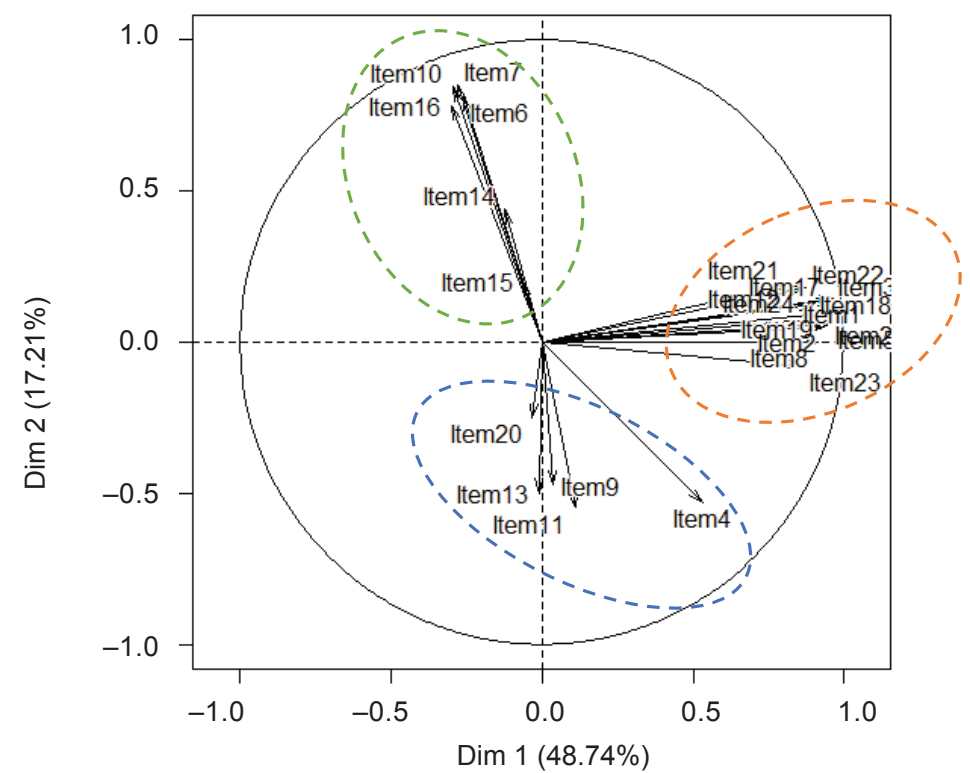

Source: Our own calculations.

\subsection{Questionnaire validity and internal consistence}

To check the questionnaire validity, we calculated the CVR values and mean values for all 25 items (Table 6). Taking in consideration the criteria presented before in the paper, were rejected those items for which CVR value is smaller than 0.5.

From the results presented in Table 6, we observe that the rejected items are: Item4, Item6, Item7, Item10 and Item16. After the elimination of 5 items, a new questionnaire with 20 items was developed. For this questionnaire was calculated the CVI value. The CVI for the final questionnaire is $C V I=\frac{17.39}{20}=0.8695$.

The internal consistency of the questionnaire which was build was evaluated using the alpha Cronbach coefficient. For the final questionnaire the alpha Cronbach coefficient is $\alpha=0.958$. This result shows us that $\alpha \geq 0.9$ and we may conclude that the internal consistency is excellent. 
Table 6 | CVR and Means Values of all Items and Acceptance or Rejection Results

\begin{tabular}{|l|c|c|c|}
\hline Item/Statement & CVR & Mean & Accept/Reject \\
\hline Item 1 & 0.87 & 1.90 & Accept \\
\hline Item 2 & 0.81 & 1.87 & Accept \\
\hline Item 3 & 0.87 & 1.91 & Accept \\
\hline Item 4 & 0.46 & 1.47 & Reject \\
\hline Item 5 & 0.81 & 1.87 & Accept \\
\hline Item 6 & 0.49 & 1.49 & Reject \\
\hline Item 7 & 0.40 & 1.44 & Reject \\
\hline Item 8 & 0.93 & 1.83 & Accept \\
\hline Item 9 & 0.87 & 1.92 & Accept \\
\hline Item 10 & 0.34 & 1.37 & Reject \\
\hline Item 11 & 0.70 & 1.81 & Accept \\
\hline Item 12 & 0.94 & 1.96 & Accept \\
\hline Item 13 & 0.85 & 1.92 & Accept \\
\hline Item 14 & 0.87 & 1.93 & Accept \\
\hline Item 15 & 0.96 & 1.98 & Accept \\
\hline Item 16 & 0.27 & 1.33 & Reject \\
\hline Item 17 & 0.87 & 1.92 & Accept \\
\hline Item 18 & 0.89 & 1.94 & Accept \\
\hline Item 19 & 0.85 & 1.91 & Accept \\
\hline Item 20 & 0.89 & 1.94 & Accept \\
\hline Item 21 & 0.94 & 1.96 & Accept \\
\hline Item 22 & 0.92 & 1.96 & Accept \\
\hline Item 23 & 0.79 & 1.88 & Accept \\
\hline Item 24 & 0.93 & 1.96 & Accept \\
\hline Item 25 & 0.83 & 1.90 & Accept \\
\hline
\end{tabular}

Source: Our own calculations

\section{Conclusion}

The present study was designed to develop a specific questionnaire for the selection of survey interviewers and personnel evaluation. For this, a first objective was to identify those characteristics that define the dimensions of survey interviewer personality. A second objective was to validate the created questionnaire if it is verified on a sample of survey interviewers which are employee in a branch of private company specialized in public opinion research.

In the present study, one of the important content validity approaches was conducted and the results showed that the final questionnaire was a valid and reliable instrument that could be used in measurement and predicting survey interviewer's characteristics. 
Those characteristics are used to create a profile of a survey interviewer. Given the personnel requirements planning and job description, this profile can be used to establish the strategies and methods of recruiting candidates for the position of survey interviewer.

Likewise, the final questionnaire allows not only finding the right people but also the entrance in the company of people with great chances to achieve performance.

However, future research should attempt to evaluate construct validity of this version. On the other hand, whereas the final questionnaire can be used to the identification of survey interviewer's characteristics, future research is needed to examine which characteristics actually predict his behaviour.

\section{Appendix}

Table A1 | Value of Each Item at the First 3 Dimensions (Dim 1, Dim 2, Dim 3) and Contribution to Their Construction $(\cos 2)$

\begin{tabular}{|c|c|c|c|c|c|c|c|c|c|}
\hline Item & Dim 1 & ctr & $\cos 2$ & $\operatorname{Dim} 2$ & ctr & $\cos 2$ & $\operatorname{Dim} 3$ & ctr & $\cos 2$ \\
\hline 1. & 0.964 & 7.624 & 0.929 & 0.147 & 0.502 & 0.022 & -0.035 & 0.057 & 0.001 \\
\hline 2. & 0.934 & 7.162 & 0.873 & 0.048 & 0.054 & 0.002 & 0.046 & 0.094 & 0.002 \\
\hline 3. & 0.955 & 7.492 & 0.913 & 0.140 & 0.457 & 0.020 & -0.026 & 0.032 & 0.001 \\
\hline 4. & 0.531 & 2. 310 & 0.281 & -0.531 & 6.543 & 0.282 & 0.454 & 9.398 & 0.206 \\
\hline 5. & 0.955 & 7.485 & 0.912 & 0.058 & 0.078 & 0.003 & 0.066 & 0.197 & 0.004 \\
\hline 6. & -0.260 & 0.553 & 0.067 & 0.812 & 15.331 & 0.660 & 0.391 & 6.970 & 0.153 \\
\hline 7. & -0.280 & 0.642 & 0.078 & 0.848 & 16.729 & 0.720 & 0.388 & 6.869 & 0.151 \\
\hline 8. & 0.911 & 6.809 & 0.830 & -0.002 & 0.000 & 0.000 & 0.125 & 0.709 & 0.016 \\
\hline 9. & 0.039 & 0.012 & 0.002 & -0.473 & 5.202 & 0.224 & 0.683 & 21.260 & 0.467 \\
\hline 10. & -0.294 & 0.709 & 0.086 & 0.846 & 16.627 & 0.716 & 0.352 & 5.647 & 0.124 \\
\hline 11. & 0.111 & 0.102 & 0.012 & -0.549 & 6.992 & 0.301 & 0.603 & 16.557 & 0.364 \\
\hline 12. & 0.821 & 5.532 & 0.674 & 0.193 & 0.868 & 0.037 & -0.073 & 0.242 & 0.005 \\
\hline 13. & -0.010 & 0.001 & 0.000 & -0.500 & 5.799 & 0.250 & 0.676 & 20.838 & 0.458 \\
\hline 14. & -0.121 & 0.121 & 0.015 & 0.438 & 4.461 & 0.192 & 0.268 & 3.281 & 0.072 \\
\hline 15. & -0.062 & 0.032 & 0.004 & 0.201 & 0.934 & 0.040 & 0.108 & 0.527 & 0.012 \\
\hline 16. & -0.301 & 0.743 & 0.091 & 0.783 & 14.251 & 0.613 & 0.263 & 3.151 & 0.069 \\
\hline 17. & 0.955 & 7.492 & 0.913 & 0.140 & 0.457 & 0.020 & -0.026 & 0.032 & 0.001 \\
\hline 18. & 0.897 & 6.602 & 0.804 & 0.125 & 0.364 & 0.016 & -0.033 & 0.049 & 0.001 \\
\hline 19. & 0.932 & 7.133 & 0.869 & 0.096 & 0.214 & 0.009 & 0.009 & 0.004 & 0.000 \\
\hline 20. & -0.033 & 0.009 & 0.001 & -0.252 & 1.478 & 0.064 & -0.104 & 0.489 & 0.011 \\
\hline 21. & 0.821 & 5.532 & 0.674 & 0.193 & 0.868 & 0.037 & -0.073 & 0.242 & 0.005 \\
\hline 22. & 0.871 & 6.221 & 0.758 & 0.180 & 0.753 & 0.032 & -0.081 & 0.298 & 0.007 \\
\hline 23. & 0.862 & 6.095 & 0.743 & -0.079 & 0.146 & 0.006 & 0.243 & 2.684 & 0.059 \\
\hline 24. & 0.871 & 6.221 & 0.758 & 0.180 & 0.753 & 0.032 & -0.081 & 0.298 & 0.007 \\
\hline 25. & 0.947 & 7.366 & 0.898 & 0.078 & 0.140 & 0.006 & 0.041 & 0.077 & 0.002 \\
\hline
\end{tabular}

Source: Our own calculations. 


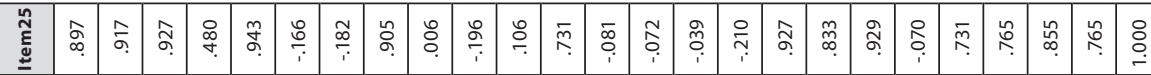

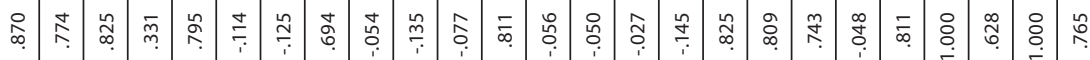

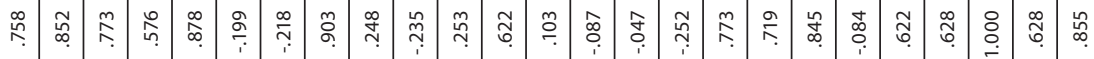

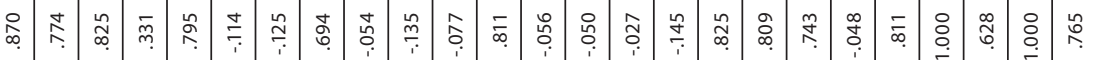

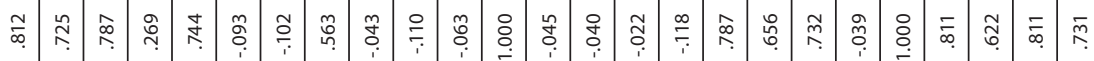

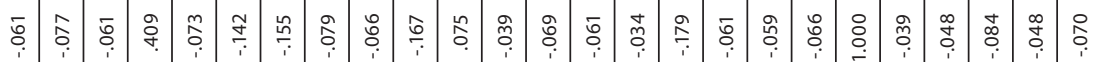

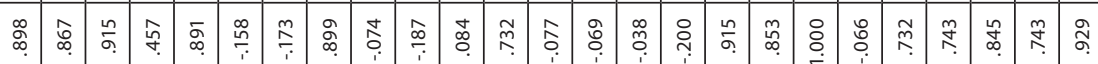

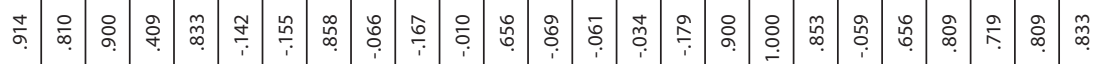

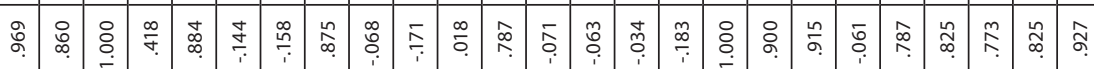

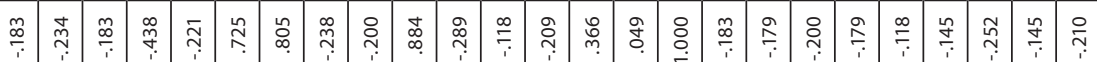

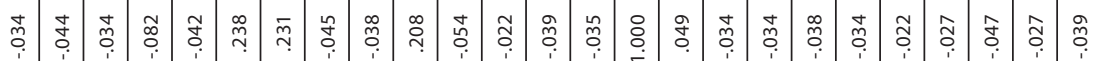

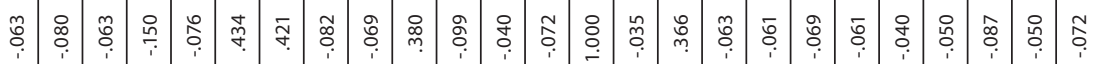

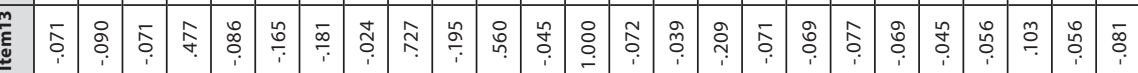

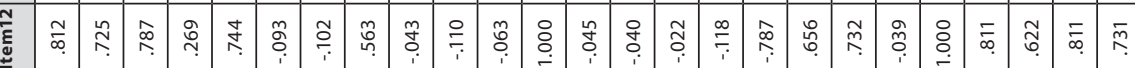

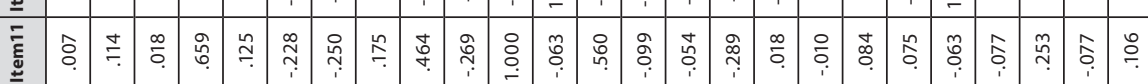

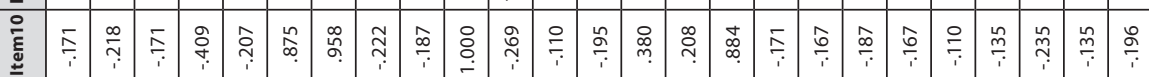

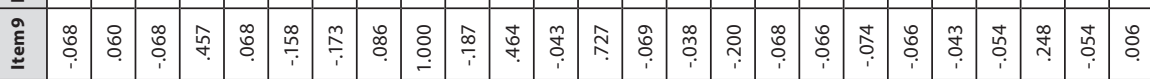

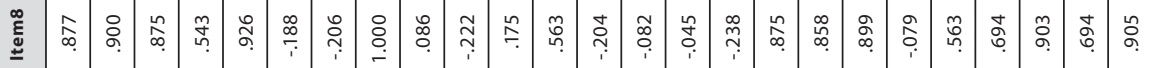

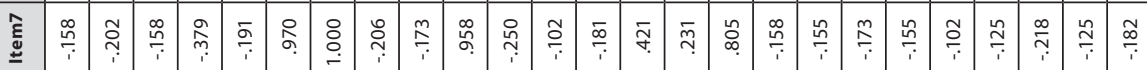

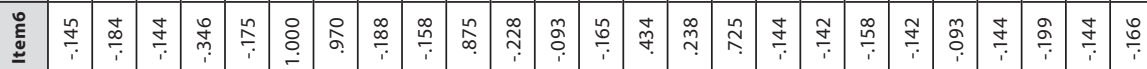

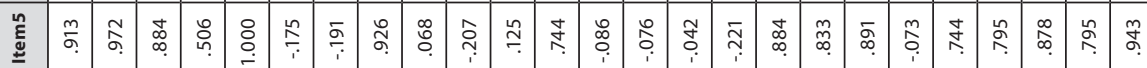

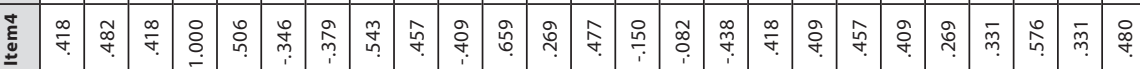

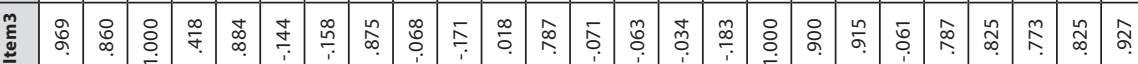

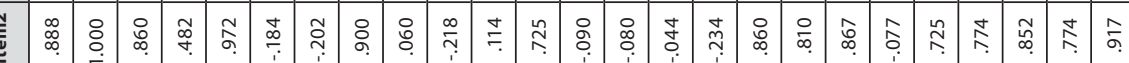

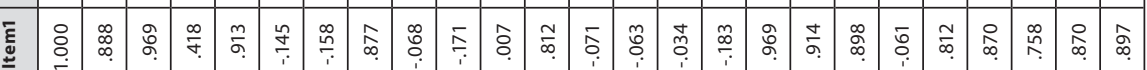

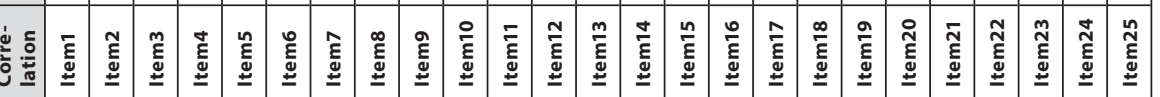




\section{References}

Abbott, C., Yost, B., Harding, J. (2003). Personality Type as a Predictor of Respondent Performance. Survey Research, 34(3), 1-16. [Retrieved 2015-11-15] Available at: http://www.srl.uic.edu/ newsletter/issues/2000s/03v34n3.pdf

Allahyari, T., Rangi, N. H., Khosravi, Y., Zayeri, F. (2011). Development and Evaluation of a New Questionnaire for Rating of Cognitive Failures at Work. International Journal of Occupational Hygiene, 3, 6-11. [Retrieved 2015-11-15] Available at: http://archiwum. ciop.pl/64167

Blaydes, L., Gillum, R. M. (2013). Religiosity-of-Interviewer Effects: Assessing the Impact of Veiled Enumerators on Survey Response in Egypt. Politics and Religion, 6(3), 459-482, https://doi.org/10.1017/S1755048312000557

Blohm, M., Hox, J., Koch, A. (2007). The Influence of Interviewers Contact Behavior on the Contact and Cooperation Rate in Face-to-Face Household Surveys. International Journal of Public Opinion Research, 19(1), 97-111, https://doi.org/10.1093/ijpor/edh120

Burger, J. M., Soroka, S., Gonzago, K., Murphy, E., Somervell, E. (2001). The Effect of Fleeting Attraction on Compliance to Requests. Personality and Social Psychology Bulletin, 27(12), 1578-1586. https://doi.org/10.1177/01461672012712002

Cortina, J. M. (1993). What Is Coefficient Alpha? An Examination of Theory and Applications. Journals of Applied Psychology, 78(1), 93-104, https://doi.org/10.1037/0021-9010.78.1.98

Couper, M. P. (2005). Technology Trends in Survey Data Collection. Social Science Computer Review, 23(4), 486-501, https://doi.org/10.1177/0894439305278972

Crano, W. D., Brewer, M. B. (1973). Principles of Research in Social Psychology. New York: McGrawHill. ISBN 978-1-4533228-8-8.

Cronbach, L. J. (1951). Coefficient Alpha and the Internal Structure of Tests. Psychometrika, 16(3), 297-334, https://doi.org/10.1007/BF02310555

Davis, D. W., Silver, B. D. (2003). Stereotype Threat and Race of Respondent Effects in a Survey on Political Knowledge. American Journal of Political Science, 47(1), 33-45, https://doi. org/10.1111/1540-5907.00003

Davis, R. E., Couper, M. P., Janz, N. K., Caldwell, C. H., Resnicow, K. (2010). Respondent Effects in Public Health Surveys. Health Education Research, 25(1), 14-26, https://doi.org/10.1093/ her/cyp046

De Leeuw, E. (2005). To Mix or not to Mix? Data Collection Modes in Surveys. Journal of Official Statistics, 21(2), 1-23. [Retrieved 2015-11-15] Available at: http://isites.harvard.edu/fs/ docs/icb.topic1327921.files/DeLeeuw2005.pdf

Dillmana, D. A., Phelps, G., Tortora, R., Swift, K., Kohrell, J., Berck, J., Messer B. L. (2009). Response Rate and Measurement Differences in Mixed-Mode Surveys Using Mail, Telephone, Interactive Voice Response (IVR) and the Internet. Social Science Research, 38(1), 1-18, https://doi.org/10.1016/j.ssresearch.2008.03.007

Digman, J. M. (1990). Personality Structure: Emergence of the Five-Factor Model. Annual Review of Psychology, 41(1), 417-440, https://doi.org/10.1146/annurev.ps.41.020190.002221

Durrant, G. B., Groves, R. M., Staetsky, L., Steele, F. (2010). Effects of Respondent Attitudes and Behaviors on Refusal in Household Surveys. Public Opinion Quarterly, 74(1), 1-36, https:// doi.org/10.1093/poq/nfp098

Dykema, J., DiLoreto, K., Price, J., White, E., Schaeffer N. C. (2012). ACASI Gender-of Respondent Voice Effects on Reports to Questions about Sensitive Behaviors among Young Adults. Public Opinion Quarterly, 76(2), 311-325, https://doi.org/10.1093/poq/nfs021 
Fillmore, C. J. (1999). A Linguistic Look at Survey Research, in Sirken, M., Herrmann, D.J., Schechter, S., Schwarz, N., Tanur, J., Tourangeau, R., ed., Cognition and Survey Research. New York: Wiley. ISBN 978-1-84860-116-1, pp. 183-19.

Ford, K., Norris, A. E. (1997). Effects of Respondent Age on Reporting of Sexual and Reproductive Behavior of Hispanic and African American Youth. Hispanic Journal of Behavioral Science, 19(3), 369-376, https://doi.org/10.1177/07399863970193008

Goldberg, L. R. (1992). The Development of Markers for the Big Five Factor Structure. Psychological Assessment, 4(1), 26-42, http://dx.doi.org/10.1037/1040-3590.4.1.26

Goldberg, L. R., Johnson, J. A., Eber, H. W., Hogan, R., Ashton, M. C., Cloninger, C. R., Gough, H. G. (2005). The International Personality Item Pool and the Future of PublicDomain Personality Measures. Journal of Research in Personality, 40(1), 84-96, http:// dx.doi.org/10.1016/j.jrp.2005.08.007

Goodwin, C. (2009). Research in Psychology: Methods and Design. Wiley. ISBN 978-0470522783.

Gosling, S. D., Rentfrow, P. J., Swann, W. B. (2003). A Very Brief Measure of the Big Five Personality Domains. Journal of Research in Personality, 37(6), 504-528, http://dx.doi. org/10.1016/S0092-6566(03)00046-1

Hansen, K. M (2007). The Effects of Incentives, Interview Length and Respondent Characteristics on Response Rates in a CATY-Study. International Journal of Public Opinion Research, 19(1), 112-121, http://dx.doi.org/10.1093/ijpor/edl022

Haunberger, S. (2010). The Effects of Respondent, Respondent and Area Characteristics on Cooperation in Panel Surveys: A Multilevel Approach. Quality \& Quantity, 44(5), 957-969, http://dx.doi.org/10.1007/s11135-009-9248-5

Härdle, W., Simar, L. (2007). Applied Multivariate Statistical Analysis. Berlin: Springer-Verlag. ISBN 3540722432.

Haynes, S., Richard, D., Kubany, E. (1995). Content Validity in Psychological Assessment: A Functional Approach to Concepts and Methods. Psychological Assessment, 7(3), 238-247, http://dx.doi.org/10.1037/1040-3590.7.3.238

Herzog, A. R., Willard, L. R. (1988). Age and Response Rates to Interview Sample Surveys. Journal of Gerontology, 43(6), 200-205, http://dx.doi.org/10.1093/geronj/43.6.S200

Holland, J. L. (1958). A Personality Inventory Employing Occupational Titles. Journal of Applied Psychology, 42(5), 336-342, http://dx.doi.org/10.1037/h0047330

Holland, J. L. (1985). Making Vocational Choices: A Theory of Careers. Englewood Cliffs, NJ: Prentice-Hall. ISBN 0135478286.

Hox, J. J., de Leeuw, E. D. (2002). The Influence of Respondents' Attitude and Behaviour on Household Survey Nonresponse: An International Comparison, in Groves, R.M., Dillman, D. A., Eltinge, J.L., Little, R.J., ed., Survey Nonresponse. New York: Wiley. ISBN: 978-0-47139627-7, pp. 103-118.

Jaba, E. (2002). Statistics. Third Edition. Economic Publisher, Bucharest. ISBN 973-590-666-X. Jäckle, A., Lynn, P., Sinibaldi, J., Tipping, S. (2013). The Effect of Respondent Experience, Attitudes, Personality and Skills on Respondent Co-operation with Face-to-Face Surveys. Survey Research Methods, 7(1), 1-15, http://dx.doi.org/10.18148/srm/2013.v7i1.4736

Johnson, R. A., Wichern, D. W. (2007). Applied Multivariate Statistical Analysis. 6th ed., Upper Saddle River: Pearson Education. ISBN 000-0131877151.

Joseph, W. B. (1982). The Credibility of Physically Attractive Communicators: A Review. Journal of Advertising, 11(3), 15-24, http://dx.doi.org/10.1080/00913367.1982.10672807 
Kane, E.W., Macaulay, L. J. (1993). Interviewer Gender and Gender Attitudes. Public Opinion Quarterly, 57(1), 1-28, http://dx.doi.org/10.1086/269352

Kenneth, K. B., Olson, J. R., Calantone, R. J., Jackson, E. C. (2002). Print versus electronic

Surveys: A Comparison of Two Data Collection Methodologies. Journal of Operations Management, 20(4), 357-373, http://dx.doi.org/10.1016/S0272-6963(02)00004-9

Kline, P. (1993). The Handbook of Psychological Testing. New York: Routledge. ISBN 978-0415211581.

Lawshe, C. (1975). A Quantitative Approach to Content Validity. Personnel Psychology, 28(4), 563-575, http://dx.doi.org/10.1.1.460.9380

Lee, J., Paek, I. (2014). In Search of the Optimal Number of Categories in a Rating Scale. Journal of Psychoeducational Assessment, 32(7), 663-673, http://dx.doi. org/10.1177/0734282914522200

Liu, M., Stainback, K. (2013). Respondent Gender Effects on Survey Responses to Marriage Related Questions. Public Opinion Quarterly, 77(2), 606-618, http://dx.doi.org/10.1093/ $\mathrm{poq} / \mathrm{nft} 019$

McDonald, H., Adam, S. (2003). A Comparison of Online and Postal Data Collection Methods in Marketing Research. Marketing Intelligence \& Planning, 21(2), 85-95, http://dx.doi. org/10.1108/02634500310465399

Mendoza, J. L., Stafford, K. L., Stauffer, J. M. (2000). Large-Sample Confidence Intervals for Validity and Reliability Coefficients. Psychological Methods, 5(3), 356-369, http://dx.doi. org/10.1037/1082-989X.5.3.356

Michell, J. (1986). Measurement Scales and Statistics: A Clash of Paradigms. Quantitative Methods in Psychology, 100(3), 398-407. [Retrieved 2015-11-15] Available at: http:// psycnet.apa.org/index.cfm?fa=buy.optionToBuy\&id=1987-09255-001

Michell, J. (1997). Quantitative Science and the Definition of Measurement in Psychology. British Journal of Psychology, 88(3), 355-383, http://dx.doi.org/10.1111/j.2044-8295.1997. tb02641.x

Murphy, J., Dean, E., Cook, S., Keating, M. (2010). The Effect of Respondent Image in a VirtualWorld Survey. RTI Press publication No. RR-0014-1012. Research Triangle Park. NC: RTI Press, http://dx.doi.org/10.3768/rtipress.2010.rr.0014.1012

Nunnally, J.C., Bernstein, I.H. (1994). Psychometric Theory (3rd ed.). New York: McGraw-Hill. ISBN 978-0070478497.

Olson, K., Bilgen, I. (2011). The Role of Respondent Experience on Acquiescence. Public Opinion Quarterly, 75(1), 99-114, http://dx.doi.org/10.1093/poq/nfq067

Osburn, H. G. (2000). Coefficient Alpha and Related Internal Consistency Reliability Coefficients. Psychological Methods, 5(3), 343-355, http://dx.doi.org/10.1037//1082-989X.5.3.343

Preston, C. C., Colman, A. M. (2000). Optimal Number of Response Categories in Rating Scale: Reliability, Validity, Discriminating Power, and Respondent Preferences. Acta Psychologica, 104, 1-15, http://dx.doi.org/10.1016/S0001-6918(99)00050-5

Schuman, H., Converse, J. M. (1971). The Effects of Black and White Respondents on Black Responses in 1968. Public Opinion Quarterly, 35(1), 44-68, http://dx.doi. org/10.1086/267866

Singer, E., Frankel, M. R., Glassman, M. B. (1983). The Effect of Respondent Characteristics and Expectations on Response. Public Opinion Quarterly, 47(1), 68-83, http://dx.doi. org $/ 10.1086 / 268767$ 
Stoetzel, J., Girard, Y. A. (1973). Les sondages d'opinion publique. (Public Opinion Polls). Presses Universitaires de France. ISBN 978-2130360513.

Summers, G. F., Hammonds, A. D. (1966). Effect of Racial Characteristics of Investigator on Self Enumerated Responses to a Negro Prejudice Scale. Social Forces, 44(4), 515-518, http://dx.doi.org/10.1093/sf/44.4.515

Tourangeau, R., Rips, L. J., Rasinski K. (2000). The Psychology of Survey Response. New York: Cambridge University Press. ISBN 978-0521576291.

Waltz, C., Strickland, O., Lenz, E. (2010). Measurement in Nursing and Health Research. Springer Publishing Company. ISBN 978-0826105073.

Webster C. (1996). Hispanic and Anglo Respondent and Respondent Ethnicity and Gender: The Impact on Survey Response Quality. Journal of Marketing Research, 33(1), 62-72, http://dx.doi.org/10.2307/3152013 